\title{
The Relationship among Social Capital, Service Types and Service Innovation Performance in Logistics Enterprises
}

\author{
Xue Tian, Chen Wang, Xiaoyi Li, Pengfei Niu, Weipeng Si \\ Beijing Wuzi University, Beijing, China \\ Email: 1826659017@qq.com
}

Received 24 July 2016; accepted 26 August 2016; published 29 August 2016

Copyright $@ 2016$ by authors and Scientific Research Publishing Inc.

This work is licensed under the Creative Commons Attribution International License (CC BY). http://creativecommons.org/licenses/by/4.0/

cC) (i) Open Access

\section{Abstract}

This study focuses on the relationship of social capital, service innovation types and service innovation performance. Through the empirical research on 210 logistics enterprises, we will find that vertical relationship capital can only promote the incremental service innovation, horizontal relationship capital can only promote the breakthrough service innovation, and social relationship capital can promote both types of service innovation. Both the two types of service innovations can improve the enterprise's service innovation performance. Finally, the research puts forward suggestions for logistics enterprises and points out the limitations and trend for future research.

\section{Keywords}

Social Capital, Service Innovation Type, Service Innovation Performance

\section{Introduction}

With the development of the service industry, service industry now is playing a more and more important role in China's national economy, and gradually becomes the core strength of the economic growth in China. Logistics is an important productive service industry which leads an important role in adjusting economic growth mode, promoting industrial structure upgrading and improving competitiveness of the national economy. However, in the fierce domestic competition environment, the cost of logistics enterprises in the ratio of GDP has been high (as shown in Figure 1), which directly restricts the long-term development of enterprises. Logistics service innovation could not only fulfill customers' needs but also effectively reduce logistics costs and improve the operating performance of the enterprises. That is the reason why logistics enterprises eager to innovate their service. But innovation cannot be separated from social capital. 


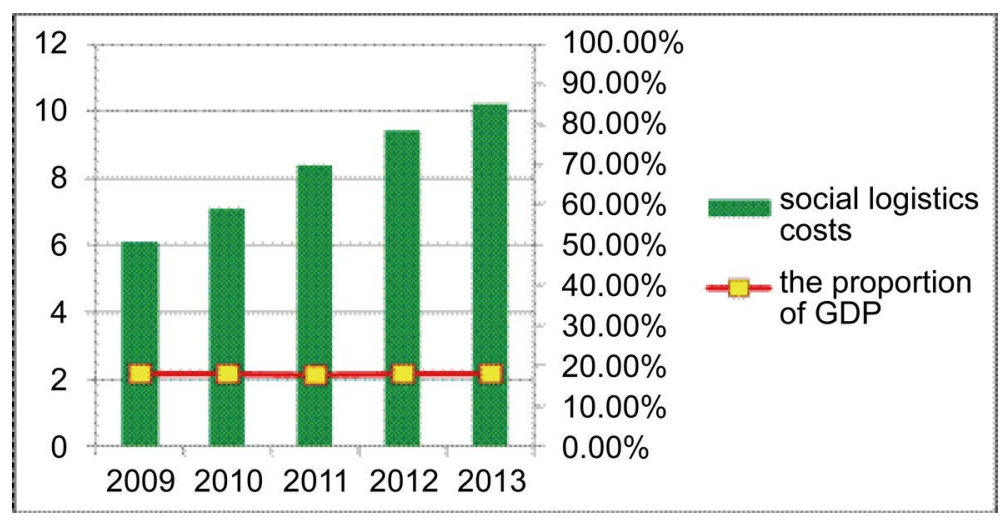

Figure 1. 2009-2013 social logistics costs.

Different dimensions of social capital also have various influences on different types of service innovation. Therefore, the logistics enterprises should strengthen contact with customers, suppliers, competitors, government, financial institutions, universities and other social organizations, in order to actively absorb and integrate social capital, which can improve the service innovation performance and help to win the competitive advantage.

\section{Theoretical Summaries}

\subsection{Social Capital}

Social capital theory boots from sociology and economics. From the perspective of sociology, the social capital emphasizes the importance of the relationships network to the social development with time going. In 1977, the French sociologist Pierre Bourdieu firstly defined the concept of social capital as the sum of individual or collective connection, it comes from the connection of the formation, maintenance and exchange of capital source (Bao Yaming, 1997) [1]. From the perspective of economics, social capital stresses the role of various resources in the relationship network to promote the economy. American scholar Loury firstly applied social capital to the research of economics and defined it as a social network among people who support or help to obtain meaningful information or resources (Loury, 1977) [2]. Later, the scholar Yli-Renk applied the social capital to the enterprise's research, and points out that the enterprise social capital is the scale and quality of the social network relationship based on trust and standard, and the ability to obtain to external information and knowledge (YliRenk et al. 2002) [3]. This definition is widely accepted by scholars. This paper will adopt Renk's definition.

From the perspective of the enterprise, social capital is divided into two types: one is from the enterprise itself. In Nahapiet's research about the link among enterprise social capital, intellectual capital and enterprise value creation, he pointed out that social capital can be divided into structural social capital, relational capital and cognitive social capital. Structure capital refers to the connection model; relational social capital refers to the assets that are generated from the relationship; cognitive social capital refers to the information and resources that can be obtained by the general characters and the cultural idea of different agency (Nahapiet et al. 1997) [4]. The other type is from the relationship between the enterprise and the external entities. The Chinese scholar Chen Jin draws on the research of the predecessors, and puts forward that the social capital contains three dimensions: vertical connection, horizontal connection and social bond. Vertical connection capital refers to the relationship between the enterprise and the supplier and the customer; horizontal connection capital refers to the relationship between the enterprise and competitive enterprise; social bond capital refers to the links between enterprises and banks, government, financial institution, industry associations and other organizations (Chen Jin et al. 2001) [5]. According to the research purpose, this study will use the research of the social capital of Chen Jin.

\subsection{Service Innovation Type}

In service economy era, although the survival and the development of enterprises will be influenced by global competition, technology, resources and information changes, the flow of personnel and other factors, there is no 
doubt that innovation is an important way for enterprises to gain competitive advantage. However, innovation is not blind, only the suitable type of innovation, could promote long-term stable development of enterprises.

Wind proposed that the product innovation is the reform of products according to the market demand and industry scale. According to the degree of the innovation, the product innovation is divided into incremental innovation and breakthrough innovation. Incremental innovation is an activity to improve enterprise performance which base on the change of the fine technology, the improvement of the product and the reform of the small product line. However, breakthrough innovation is to create a new service or technology, and to change the market demand (Wind et al. 1997) [6]. On the research of the innovation type, Xiong Wei learned from Tushuman, pointed out that increment innovation is to improve product quality and performance of the customer's attention and enterprise existing; breakthrough innovation is to reform the existing technology and existing products. Increment innovation can continue to obtain a stable profit; breakthrough innovation is a tool for enterprise to seize the market, but with huge risk (Xiong Wei et al. 2010) [7]. Wu Xiaoyun who based on the previous research results summarized breakthrough innovation is a creative development, it refers to the enterprise has never had an innovative behavior, and will develop new products or services for the market, breakthrough innovation can make the enterprise in the changing market to occupy a favorable position, to provide a valuable opportunity for the enterprise, however, high income means high risk, such an innovation approach does not bring profit or need long time to bring profit. Increment innovation refers to perfect and improve the existing products and services in the market, to find the solution to increase profits from the feedback of the customers and suppliers (Wu Xiaoyun et al. 2013) [8]. This research will continue to use that foreign scholars Wind's classification and definition of the service innovation types which is divided into incremental service innovation and breakthrough service innovation.

\subsection{Service Innovation Performance}

Innovation performance is to make the company have the ability to create and distribute to maintain long-term business performance. Sun Ying thinks that service innovation performance is the ability of enterprises to develop new services or improve the existing services to meet the needs of enterprises themselves, suppliers, customers and internal staff and other stakeholders in order to maintain the competitive edge of the enterprise (Sun Ying, 2009) [9]. Wang Jiabao puts forward that service innovation performance is a complex concept, the premise of establishing the concept of service innovation is to make clear the factors that affect the service innovation performance, generally includes the service innovation idea, the leader's support to the service innovation, the service innovation organization structure and the service innovation flow design and completion situation (Wang Jiabao, 2011) [10]. This paper studies on the logistics enterprises will follow the Sun Ying on service innovation performance definition.

\section{Research Hypotheses and Concept Model}

\subsection{Social Capital and Service Innovation Type}

With the rapid changes in the market environment, the resources needed for innovation of the enterprises become complex, Even the large enterprises need to absorb and integrate social capital in order to achive service innovation (Heikkinen et al. 2007) [11]. Social capital can make enterprises and their partener have the same goals and values, which could promote the absorption and digestion of information and knowledge among enterprises, achieve effective communication and create new ideas (Damanpour, 1991) [12]. Specifically, during the interactive communication process, on the one hand, the enterprise could be more familiar with the existing information and resources, deepen the understanding of their knowledge, and lead to more service innovation; on the other hand, it can make enterprises access to the latest information and knowledge, breaking the boundaries of the existing knowledge, to promote the creation of the breakthrough service innovation activities (Zhang Huiying et al. 2014) [13].

Therefore, according to the logistics enterprise, this research puts forward the following research hypotheses:

1) vertical relationship capital of logistics enterprise has a positive effect on the incremental innovation;

2) horizontal relationship capital of logistics enterprise has a positive effect on the incremental innovation;

3) social relationship capital of logistics enterprise has a positive effect on the incremental innovation;

4) vertical relationship capital of logistics enterprise has a positive effect on the breakthrough innovation; 
5) horizontal relationship capital of logistics enterprise 1 has a positive effect on the breakthrough innovation;

6) social relationship capital of logistics enterprise has a positive effect on the breakthrough innovation.

\subsection{Service Innovation Type and Service Innovation Performance}

For enterprise, the improvement of different ways of innovation has various utility. On the one hand, through breakthrough innovation, enterprises can have priority to competitors in obtaining the knowledge and information required for innovation (Lieberman et al. 1995) [14]. they could be the first to occupy the market, so that customers have a better understanding of innovation services, and prior to competing companies to obtain customers information (Szymanski et al. 1995) [15], and even change the customer's consumption behavior, and then get better business performance (Day et al. 1988) [16]; on the other hand, through incremental innovation, the enterprises focusing on the existing demand change, will provide customers with additional value-added services, which can meet the needs of customers, so as to improve the performance of enterprises (Garcia et al. 2002) [17]. In addition, because the incremental innovation is based on the existing ability to service innovation, so the cost is very low, the risk is smaller and the stability is high (Levinthal et al. 1993) [18].

Therefore, according to logistics enterprise, this research puts forward the following research hypotheses:

7) incremental service innovation has a positive effect on service performance of logistics enterprise;

8) breakthrough service innovation has a positive effect on service performance of logistics enterprise.

\subsection{Construction of the Initial Concept Model}

Through the above research hypothesis, we can construct the initial concept model of the interaction between the logistics enterprise social capital, service innovation performance and service innovation type (as shown in Figure 2).

\section{Data Collection and Variable Measure}

\subsection{Sample and Data}

This study uses a questionnaire to collect sample data, sample covers a very wide range, including logistics companies in manufacturing enterprises, logistics consulting company, transportation companies, logistics parks and other institutions. On the one hand, the author through the logistics industry for the issuance and recovery of the questionnaire; on the other hand, the author also through the mail, micro channel platform, QQ and other ways to distribute and to recover the questionnaire. The total of 500 questionnaires was distributed, 256 questionnaires were returned, the recovery rate was $51.2 \%$, and the final qualified questionnaire was 213 , and the effective rate was $42.6 \%$. In order to ensure the reliability of the questionnaire, the respondents are mainly the managers of the logistics enterprises who have long working experience; the setting of all kinds of items is based on the literature research, and modified according to field survey and expert opinion.

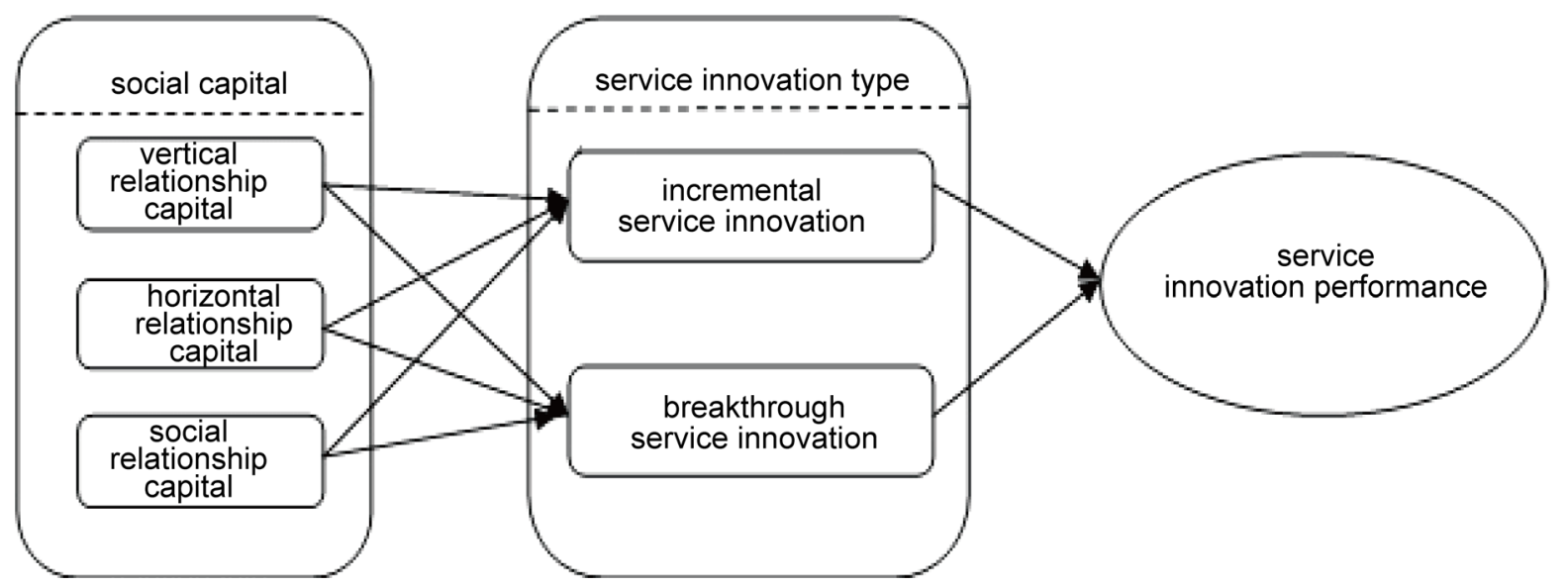

Figure 2. The initial concept model of the interaction among the logistics enterprise's social capital, service innovation performance and service innovation type. 


\subsection{Variable Measure}

The latent variables involved in this study include the vertical relationship capital, the horizontal relationship capital, the social relationship capital, incremental service innovation, breakthrough service innovation and service innovation performance. Because these latent variables are difficult to measure, this study uses the Likert seven scale methods to measure the scale, for different questions, according to the actual situation of the enterprise to choose the scoring from 1 - 7 from disagree to agree.

\subsubsection{Enterprise Social Capital}

In the measurement of the vertical relationship capital, the horizontal relationship capital, the social relationship capital, the measurement of the various latent variables of social capital of this survey is shown in Table 1.

\subsubsection{Service Innovation Type}

In the measurement of incremental service innovation and breakthrough service innovation, the measurement of the various latent variables of service innovation type of this survey is shown in Table 2.

Table 1. Measurement items of social capital.

\begin{tabular}{|c|c|c|}
\hline Latent variables & Measurement items & Reference documentation \\
\hline $\begin{array}{l}\text { The vertical } \\
\text { relationship } \\
\text { capital }\end{array}$ & $\begin{array}{l}\text { a1. The number of contacts between the enterprise and clients } \\
\text { (the owner of the business, manufacturer, retailers, etc.) } \\
\text { a2. The number of clients connected to the enterprise } \\
\text { a3. The number of contacts between the enterprise and the supplier } \\
\text { (team owner, warehouse owner, etc.) } \\
\text { a4. The number of suppliers connected to the enterprise }\end{array}$ & \multirow{3}{*}{$\begin{array}{l}\text { (Bian Yanjie, et al. 2000) [19], } \\
\text { (Chen Jin, et al. 2001), } \\
\text { (Adler, 2002) [20], } \\
\text { (Zhang Fanghua, et al. 2004) [21] }\end{array}$} \\
\hline $\begin{array}{l}\text { The horizontal } \\
\text { relationship } \\
\text { capital }\end{array}$ & $\begin{array}{l}\text { a5. The number of contacts between the enterprise and competitive enterprises } \\
\text { (learning from the opponent's service model, technology, etc.) } \\
\text { a6. The number of competitive enterprises connected to the enterprise } \\
\text { a7. The number of contacts between the enterprise and other logistics enterprises } \\
\text { (participate in seminars and cooperate with each other, etc.) } \\
\text { a8. The number of other logistics enterprises connected to the enterprise }\end{array}$ & \\
\hline $\begin{array}{l}\text { The social } \\
\text { relationship } \\
\text { capital }\end{array}$ & $\begin{array}{l}\text { a9. The number of contacts between the enterprise and universities } \\
\text { (recruitment, school enterprise cooperation) } \\
\text { a10. The number of universities connected to the enterprise } \\
\text { a11. The number of contacts between the enterprise and governments } \\
\text { (promulgated the relevant logistics policies, the introduction of } \\
\text { preferential policies, etc.) } \\
\text { a12. The number of governments connected to the enterprise } \\
\text { a13. The number of contacts between the enterprise and scientific research institutions } \\
\text { (China Federation of purchasing, China Logistics Association, etc.) } \\
\text { a14. The number of scientific research institutions connected to the enterprise } \\
\text { a15. The number of contacts between the enterprise and financial institutions } \\
\text { (banks, securities, insurance companies, etc.) } \\
\text { a16. The number of financial institutions connected to the enterprise }\end{array}$ & \\
\hline
\end{tabular}

Table 2. Measurement items of service innovation types.

\begin{tabular}{|c|c|c|}
\hline Latent variables & Measurement items & Reference documentation \\
\hline $\begin{array}{l}\text { Incremental } \\
\text { service } \\
\text { innovation }\end{array}$ & $\begin{array}{l}\text { b1. The frequency of the value added services provided and service content } \\
\text { extended by the enterprise to the existing customers and markets } \\
\text { b2. The frequency of the existing service mode and the distribution line } \\
\text { adjusted and improved by the enterprise } \\
\text { b3. The frequency of the existing technology finely adjusted and improved } \\
\text { by the enterprise }\end{array}$ & \multirow{2}{*}{$\begin{array}{l}\text { (Zhang Jing, 2011) [22], } \\
\text { (Li Xianjia, 2013) [23], } \\
\text { (Zhang Huiying, et al. 2014), } \\
\text { (Wei Jiang, et al. 2014) [24] }\end{array}$} \\
\hline $\begin{array}{l}\text { Breakthrough } \\
\text { service } \\
\text { innovation }\end{array}$ & $\begin{array}{l}\text { b4. The frequency of the new customers and new markets found by the enterprise } \\
\text { b5. The frequency of new service mode and new distribution line developed by the } \\
\text { enterprise } \\
\text { b6. The frequency of the emerging logistics technology updated and used } \\
\text { by the enterprise }\end{array}$ & \\
\hline
\end{tabular}




\subsubsection{Service Innovation Performance}

In the measurement of the logistics enterprise service innovation performance, the measurement items of this survey are shown in Table 3.

\subsection{Data Analysis and Hypothesis Verification}

\subsubsection{Descriptive Statistical Analysis}

This study collected 213 valid questionnaires, and the basic information is shown in Table 4. In order to ensure that the data obtained from the questionnaire can reflect the situation of the sample logistics enterprise comprehensively, the research mainly aims at the different levels of people in logistics enterprises and scholars who have been engaged in the research of logistics enterprises to carry on the questionnaire survey. Among responsers, shareholders and directors accounted for 1.32\%; in senior management personnel accounted for 9.27\%; in middle management personnel accounted for 13.91\%; in the grass-roots management of personnel accounted for $15.89 \%$; general staff accounted for $16.56 \%$; scholars and researchers accounted for 43.05 .

Table 3. Measurement items of service innovation performance.

\begin{tabular}{|c|c|c|}
\hline Latent variables & Measurement items & Reference documentation \\
\hline $\begin{array}{l}\text { Service } \\
\text { innovation } \\
\text { performance }\end{array}$ & $\begin{array}{l}\text { c1. Service innovation performance of the enterprise improves the company's sales } \\
\text { c2. Service innovation performance of the enterprise improves the company's return on } \\
\text { investment } \\
\text { c3. Service innovation performance of the enterprise improves customer satisfaction } \\
\text { c4. Service innovation performance of the enterprise brings a large number of customers } \\
\text { c5. Service innovation performance of the enterprise improves the company's } \\
\text { development potential }\end{array}$ & $\begin{array}{l}\text { (Wang Jiabao, 2010), } \\
\text { (Zhang Jing, 2011), } \\
\text { (Zhang Fanghua, 2006) [25] }\end{array}$ \\
\hline
\end{tabular}

Table 4. Basic information of sample enterprises.

\begin{tabular}{|c|c|c|c|}
\hline Characteristic & Category & Frequency & Percentage \\
\hline \multirow{6}{*}{ Responsers } & Shareholders or directors & 2 & $1.32 \%$ \\
\hline & Senior management personnel & 14 & $9.27 \%$ \\
\hline & Middle management personnel & 21 & $13.91 \%$ \\
\hline & The grass-roots management of personnel & 24 & $15.89 \%$ \\
\hline & General staff & 25 & $16.56 \%$ \\
\hline & Scholars or researchers & 65 & $43.05 \%$ \\
\hline \multirow{4}{*}{ The age of enterprises } & 1 - 3 years & 52 & $34.44 \%$ \\
\hline & 3 - 5 years & 42 & $27.81 \%$ \\
\hline & 5 - 10 years & 36 & $23.84 \%$ \\
\hline & More than 10 years & 21 & $13.91 \%$ \\
\hline \multirow{5}{*}{ The number of staff } & $\leq 20$ & 3 & $1.99 \%$ \\
\hline & $20-100$ & 35 & $23.18 \%$ \\
\hline & $101-299$ & 42 & $27.81 \%$ \\
\hline & $200-999$ & 43 & $28.48 \%$ \\
\hline & $\geq 1000$ & 26 & $18.54 \%$ \\
\hline \multirow{4}{*}{ The annual turnover of enterprises } & $\leq 500$ million & 48 & $31.79 \%$ \\
\hline & 300 million - 3000 million & 64 & $42.38 \%$ \\
\hline & 3000 million - 3 billion & 26 & $17.22 \%$ \\
\hline & More than 3 billion & 13 & $8.61 \%$ \\
\hline
\end{tabular}


From the age of the enterprise, in order to reflect the basic characteristics of logistics enterprises in different age stages, the sample enterprises include the newly established logistics companies and veteran logistics enterprises, which set up 1 - 3 years of enterprise accounted for $34.44 \%$; founded 3 - 5 years of enterprises accounted for $27.81 \%$; founded 5 - 10 years of enterprise accounted for $23.84 \%$; founded more than 10 years accounted for $13.91 \%$.

From the enterprise scale, the sample can reflect the small, medium and large sized logistics enterprises comprehensively. Enterprises in the sample logistics enterprises in less than 20 people accounted for $1.99 \% ; 20$ - 100 people's business accounted for 23.18\%; 100 - 299 people’s business accounted for 27.81\%; 300 - 399 people’s business accounted for $28.48 \%$; more than 1000 people's business accounted for $18.54 \%$.

From the annual turnover of the enterprise, sample logistics enterprises not only contain the very high efficiency of logistics enterprises, but also contain poor efficiency of logistics enterprises. Which is less than 500 million of enterprises accounted for 31.79\%; in the 500 million - 3000 million enterprises accounted for 42.38\%; in the 3000 million - 3 billion enterprises accounted for 17.22\%; more than 3 billion of enterprises accounted for $8.61 \%$.

\subsubsection{Validity and Reliability of the Questionnaire}

The validity reflects the measurement tool accuracy to measure the degree of the indicators to measure. In general, the validity includes two aspects of content validity and structural validity. The questionnaire developed by this research is based on the frontier theory, and combined with the opinions of experts and the views of the enterprise, so that the questionnaire has a high content validity. For the structural validity of the questionnaire, this study adopts the measurement of KMO sample and Bartlett's sphere test to measure the validity of the data; the results are shown in the following Table 5. KMO of social capital, service innovation types and service innovation performance are more than 0.8 , significance level is 0.000 , the accumulative explained variance also reached more than $80 \%$, factor loading of each item, as shown in Table 6 , is more than 0.5 , reaching statistical requirements. Therefore, the scale of this study passes the validity test.

The reliability reflects the internal consistency and stability of the measurement results, and the ratio of the total variance to the sample variance is expressed in the numerical values. In this paper, we use the Cronbach's $\alpha$ coefficient to test the reliability of the variables, usually Cronbaeh'a coefficient is more than 0.9 , that the internal reliability of the scale is very high; Cronbach's $\alpha$ coefficient is between 0.8 and 0.9 , that the internal reliability of the scale is high; Cronbach's $\alpha$ coefficient is between 0.7 and 0.8 , that the scale can be accepted; Cronbaeh'a coefficient is less than 0.7, that there are some problems in the scale, which need to be redesigned. Cronbach's $\alpha$ coefficients of this survey are shown in Table 6 , are all more than 0.7 , the scale of this study passes the reliability test.

\subsubsection{Construction of Structure Equation Model}

Because of the high reliability and validity of the questionnaire in this survey, the questionnaire can construct the structural equation model. On the basis of the original conceptual model constructed as mentioned above, we set up initial structure equation model, as shown in Figure 3. The model through 16 exogenous variables (a1, a2, a3, a4, a5, a6, a7, a8, a9, a10, a11, a12, a13, a14, a15, a16) to measure 3 exogenous latent variables (vertical relationship capital, horizontal relationship capital, social relationship capital), setting 11 endogenous variables (b1, b2, b3, b4, b5, b6, b7, b8, b9, b10, b11) to measure 3 endogenous variables (breakthrough service innovation, incremental service innovation, service innovation performance).

Table 5. Validity and reliability of variables.

\begin{tabular}{|c|c|c|c|c|c|c|}
\hline \multirow[t]{2}{*}{$\begin{array}{c}\text { Test index } \\
\text { Latent variables }\end{array}$} & \multirow[t]{2}{*}{ KMO } & \multicolumn{3}{|c|}{ Bartlett's sphere test results } & \multirow[t]{2}{*}{$\begin{array}{l}\text { Cumulative explained } \\
\text { variance }\end{array}$} & \multirow[t]{2}{*}{ The result } \\
\hline & & $\begin{array}{c}\text { Approximate } \\
\text { Chi-square value }\end{array}$ & & $\begin{array}{c}\text { Significance } \\
\text { level }\end{array}$ & & \\
\hline Social capital & 0.843 & 509.706 & 120 & 0.000 & $84.377 \%$ & Pass \\
\hline Service innovation type & 0.871 & 161.515 & 15 & 0.000 & $87.077 \%$ & Pass \\
\hline Service innovation performance & 0.897 & 191.909 & 15 & 0.000 & $86.241 \%$ & Pass \\
\hline
\end{tabular}


Table 6. KMO values and the Bartlett statistics of the sample data.

\begin{tabular}{|c|c|c|c|}
\hline Variables & Item & Factor loading & Cronbach's $\alpha$ coefficients \\
\hline \multirow{5}{*}{ Vertical relationship capital } & a1 & 0.679 & \multirow{5}{*}{0.795} \\
\hline & a2 & 0.525 & \\
\hline & a3 & 0.686 & \\
\hline & $\mathrm{a} 4$ & 0.555 & \\
\hline & a5 & 0.657 & \\
\hline \multirow{3}{*}{ Horizontal relationship capital } & a6 & 0.585 & \multirow{3}{*}{0.798} \\
\hline & a7 & 0.618 & \\
\hline & a8 & 0.586 & \\
\hline \multirow{8}{*}{ Social relationship capital } & a9 & 0.598 & \multirow{8}{*}{0.808} \\
\hline & $\mathrm{a} 10$ & 0.608 & \\
\hline & $\mathrm{a} 11$ & 0.700 & \\
\hline & $\mathrm{a} 12$ & 0.735 & \\
\hline & $\mathrm{a} 13$ & 0.603 & \\
\hline & a14 & 0.767 & \\
\hline & $\mathrm{a} 15$ & 0.601 & \\
\hline & $\mathrm{a} 16$ & 0.576 & \\
\hline \multirow{3}{*}{ Breakthrough service innovation } & b1 & 0.547 & \multirow{3}{*}{0.894} \\
\hline & b2 & 0.721 & \\
\hline & b3 & 0.702 & \\
\hline \multirow{3}{*}{ Incremental service innovation } & b4 & 0.652 & \multirow{3}{*}{0.792} \\
\hline & b5 & 0.659 & \\
\hline & b6 & 0.695 & \\
\hline \multirow{5}{*}{ Service innovation performance } & $\mathrm{c} 1$ & 0.822 & \multirow{5}{*}{0.839} \\
\hline & c2 & 0.788 & \\
\hline & c3 & 0.827 & \\
\hline & c4 & 0.830 & \\
\hline & c5 & 0.805 & \\
\hline
\end{tabular}

Through calculation and analysis, the fitting indexes are shown in Table 7, NFI, IFI and CFI are all less than 0.9 , which are not within the scope of acceptance. Therefore, the model needs revision.

Because the index of the measurement model doesn't reach the requirements, only be modified to obtain a better fitting effect. The common correction method is to delete the rote of the largest correction index (MI), recalculating the measurement model. However, the rote to delete not only needs to have data support, but also need to have a realistic basis. By observing the correction index results, we can observe that the MI of e16 and e15 are all 50.287, the MI of e14 and e13 are all 32.840, the MI of e10 and e9 are all 27.638; far higher than the other MI. Item 9 is the number of contacts between the enterprise and universities (recruitment, school enterprise cooperation), taking into account the enterprise generally will not go to a school for school recruitment, so we can consider deleting this item; item 13 is the number of contacts between the enterprise and scientific research institutions (China Federation of purchasing, China Logistics Association, etc.), taking into account most 


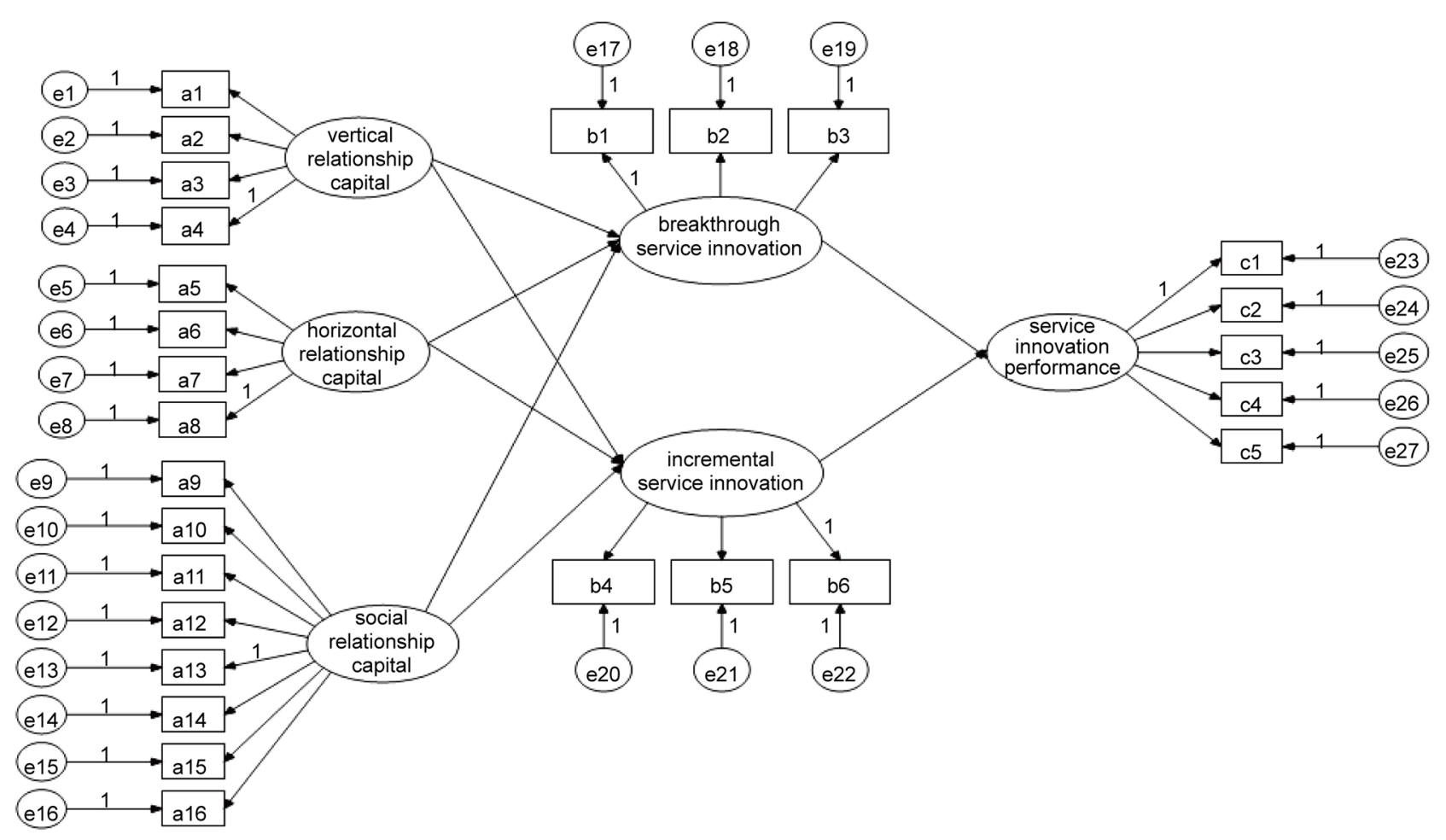

Figure 3. Initial structure equation model based on conceptual model.

Table 7. The fitting index of the basic initial concept.

\begin{tabular}{|c|c|c|c|}
\hline Parameter & Numerical value & Reference value & The result \\
\hline$\chi^{2}$ & 578.213 & - & - \\
\hline $\mathrm{df}$ & 261 & - & - \\
\hline$\chi^{2} / \mathrm{df}$ & 2.215 & $1-3$ & Pass \\
\hline NFI & 0.842 & $\geq 0.900$ & Not pass \\
\hline IFI & 0.874 & $\geq 0.900$ & Not pass \\
\hline TLI & 0.910 & $\geq 0.900$ & Pass \\
\hline CFI & 0.864 & $\geq 0.900$ & Not pass \\
\hline RSMEA & 0.079 & $<0.080$ & Pass \\
\hline
\end{tabular}

of the enterprise staff are all middle managers, grassroots managers and ordinary employees in this questionnaire survey, they basically have no qualification to represent the enterprise to participate in the logistics meeting, so we can consider deleting the item; item 15 is the number of contacts between the enterprise and financial institutions (banks, securities, insurance companies, etc.), taking into account the reality of the situation, the bank generally will not multiply loan to the same logistics enterprise in short time., so we can consider deleting this item. This survey follows the method of deleting items a15, a13 and a9 in proper order. The modified measurement model is shown in Figure 4.

Through calculation and analysis, the fitting index is shown in Table 8, the indexes are within the scope of acceptance, the optimal structure model is shown in Figure 5, fitting results are shown in Table 9.

\subsection{Interpretation of Result}

Through the fitting results of structural equation model, it is found that 8 original hypotheses which the interaction 


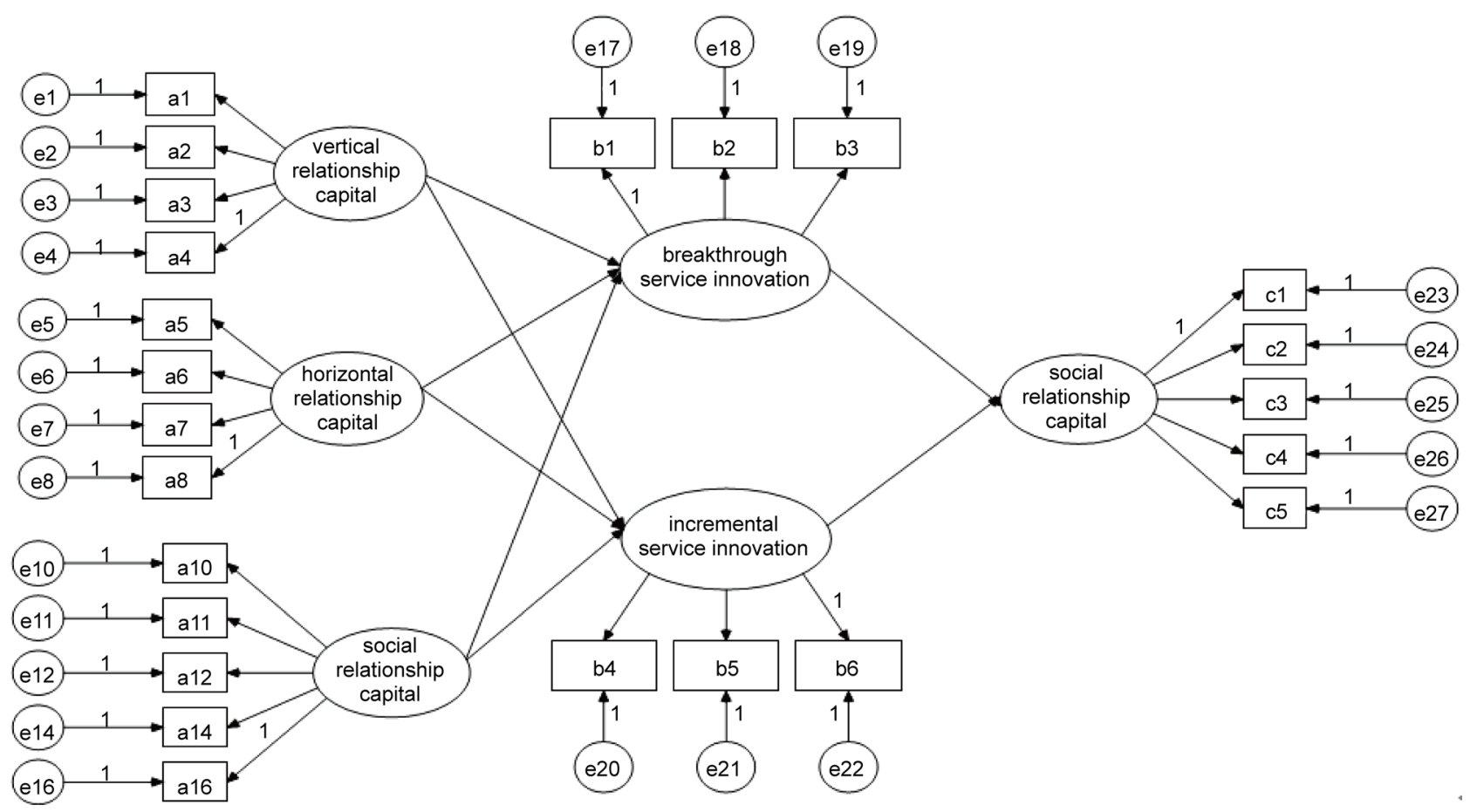

Figure 4. Modified structure equation model.

Table 8. Modified fit index.

\begin{tabular}{cccc}
\hline Parameter & Numerical value & Reference value & The result \\
\hline$\chi^{2}$ & 626.883 & - & - \\
df & 274 & - & Pass \\
$\chi^{2} / \mathrm{df}$ & 2.540 & $1-3$ & Pass \\
NFI & 0.931 & $\geq 0.900$ & Pass \\
IFI & 0.925 & $\geq 0.900$ & Pass \\
TLI & 0.945 & $\geq 0.900$ & $\geq 0.900$ \\
CFI & 0.905 & $<0.080$ & Pass \\
RSMEA & 0.057 & & Pass \\
\hline
\end{tabular}

between the social capital of logistics enterprises and service innovation influence the service innovation performance are not all supported. Horizontal social capital has a positive effect on incremental service innovation which is not supported, hypothesis 2 is not established. This indicates that the logistics enterprises to strengthen the contact with suppliers and customers and will not promote the enterprise to break through service innovation. Because the logistics enterprises have formed a good partnership with the suppliers and customers, the regular interaction and communication have formed a fixed model, which makes the logistics enterprises cannot absorb new knowledge and resources from customers and suppliers. In order to maintain the existing customers and suppliers, logistics enterprises have no energy and resources to expand the channels and to open up new customers, also can not promote enterprises to break through service innovation. Vertical social capital has a positive effect on breakthrough service innovation is not also supported, hypothesis 4 is not established. This indicates that the level of development of China's logistics enterprises is still uneven, small and medium enterprises learn the technology and model from large logistics enterprises which is not suitable for the improvement of its own service model because of the limitations of the enterprise itself; the large logistics enterprises also do not 


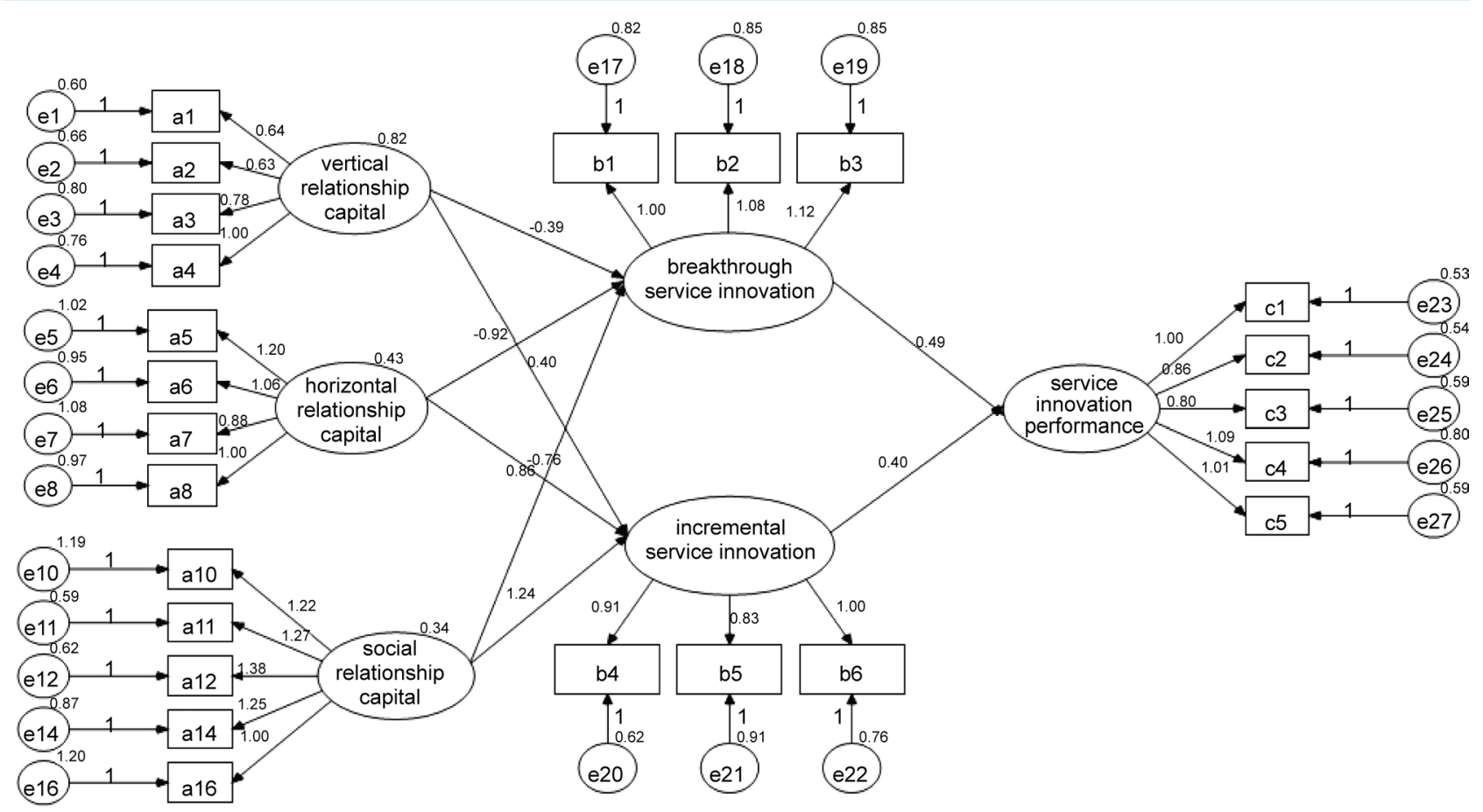

Figure 5. The structure model of mechanism of the modified social capital on service innovation of logistics enterprises.

Table 9. Modified fit result $(\mathrm{N}=133)$.

\begin{tabular}{lccccccc}
\hline & Route & & Route coefficient & Standard route coefficient & C.R. & P \\
\hline Breakthrough service innovation & $\leftarrow$ & Vertical relationship capital & -0.393 & -0.214 & -4.432 & $* * *$ \\
Breakthrough service innovation & $\leftarrow$ & Horizontal relationship capital & 0.917 & 0.697 & 5.017 & $* * *$ \\
Breakthrough service innovation & $\leftarrow$ & Social relationship capital & 0.855 & 0.586 & 4.422 & $* * *$ \\
Incremental service innovation & $\leftarrow$ & Vertical relationship capital & 0.398 & 0.579 & 4.324 & $* * *$ \\
Incremental service innovation & $\leftarrow$ & Horizontal relationship capital & -0.764 & -0.324 & -4.674 & $* * *$ \\
Incremental service innovation & $\leftarrow$ & Social relationship capital & 1.236 & 0.763 & 4.902 & $* * *$ \\
Service innovation performance & $\leftarrow$ & Incremental service innovation & 0.395 & 0.690 & 5.640 & $* * *$ \\
Service innovation performance & $\leftarrow$ & Breakthrough service innovation & 0.494 & 0.778 & 5.710 & $* * *$ \\
\hline
\end{tabular}

bother to go to the small and medium-sized logistics enterprises to visit and study, is not enough to promote the incremental service innovation of the enterprise, while the rest of hypotheses is supported. All the research hypotheses are verified as show in Table 10.

\subsection{Modification of Concept Model}

Since not all of the research hypotheses are verified, it is necessary to revise the initial concept model of the interaction between social capital of logistics enterprises, service innovation type and service innovation performance, modified concept model is shown in Figure 6.

\section{Conclusion}

\subsection{Suggestions}

This study was based on the empirical analysis of 213 logistics enterprises; improvements for the logistics business are suggested on empirical findings. 
Table 10. All kinds of research hypotheses verification summary.

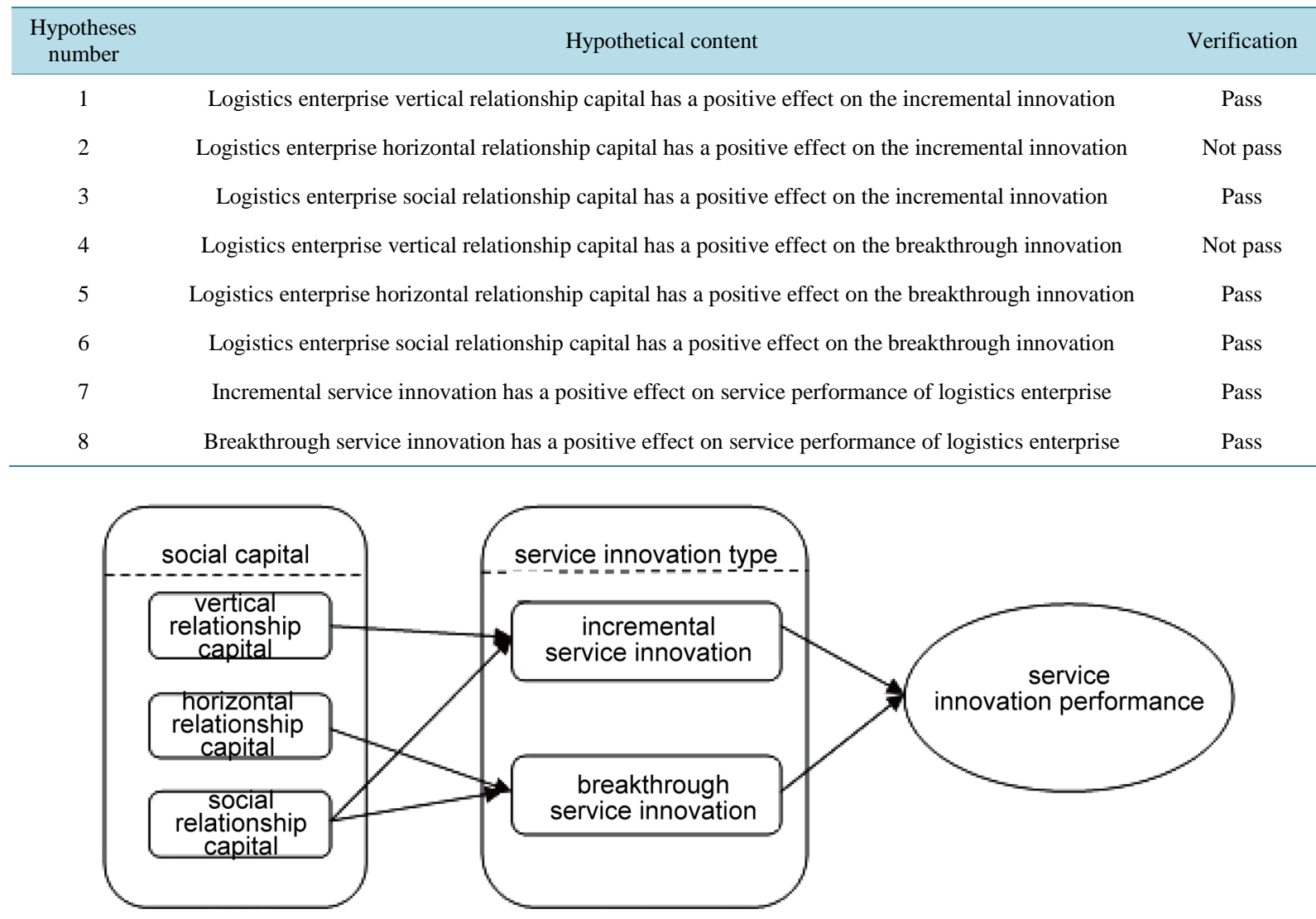

\section{Figure 6. Modified concept.}

1) From the perspective of a vertical relationship, corporate senior managers should frequently give letters and calls to large customers and suppliers, held on a regular basis seminars and recreational activities annually, and listen to their suggestions and comments actively, make improvements on the company's own service level and technology at any time, and strive to provide customers with value-added services to meet customers and suppliers of the individual needs, enabling enterprises to improve business performance through continuous incremental innovation activities.

2) From the perspective of horizontal relations, enterprises shall regularly organize senior managers to visit and communicate with the competitors, learn from the advanced technology and management experience, to break their own shackles of traditional skills, to seek a breakthrough of innovation companies. Meanwhile, enterprises should strengthen cooperation with other logistics enterprises, form strategic alliances, and expand the business scope continuously.

3) From the perspective of social relations, first of all, enterprises should actively participate in the conference organized by the Association of the logistics industry, learn and absorb the latest theoretical achievements, firmly grasp the direction of service innovation; secondly, business recruit high-quality talent of logistics industry through university recruitment, the new ideas and new ideas introduced to the company; again, under the various preferential policies of government to support enterprises make adjustments in their own development direction and goals; and finally, enterprises and financial institutions to work closely under increasing emergence of the environment in supply chain finance, and constantly open up new business. On the one hand, the enterprise under the guidance of industry associations, and improve the existing service model and technology constantly, continuous innovation will be incremental services; on the other hand, businesses in government policy related logistics as well as new ideas and thinking support, efforts the needs of enterprises breakout of service innovation.

4) From the perspective of enterprises own, on the one hand, companies should encourage employees to 
learning new skills on the own, support staff learn and absorb external information resources consciously in peacetime work. While enterprises should hold Innovation Competition, to encourage employees to actively creation, and translating the results of innovation for the economic efficiency of enterprises; on the other hand, when business executives in developing service innovation strategy, we must clearly recognize their own abilities and the future development direction of the enterprise, despite the break-service innovation will lead to higher business performance, but often accompanied with high risk, and incremental service innovation generally brought about slightly lower economic performance, also the risk is low.

\subsection{Future Research}

\subsubsection{The Innovation of This Study}

1) The social capital theory applied to the study of logistics enterprises. In the existing literature, explored the literature of logistics enterprises service innovation from the perspective of social capital theory is little. In this study, we will apply the study of social capital to service innovation, exploring the influence of social capital for the logistics business service innovation, widening the perspective of social capital research.

2) In the service sector, the innovation type is subdivided into breakout-style service innovation and gradual service innovation, and researched the influence of two different types of to service innovation performance. Scholars' research for the enterprise innovation types from the perspective of the majority of products, marketing and technology, for service innovation type of research, in my reading of the literature is also little research in this area. The study for the logistics companies to explore the effects of two different types of service innovation and service innovation performance, enrich the theoretical system of innovation services.

3) Research combined with social capital, innovation type and innovation performance. In the current literature that I have read, social capital with innovation type, social capital with innovation performance, as well as innovative type with innovation performance of combination has many, but the combination of all three studies in the literature is not much. For this study, the logistics business, social capital, innovation type and innovation performance combine empirical study to develop a broader perspective for future research.

\subsubsection{Defects in This Study}

Because of the complexity of the research questions and the limitation of my personal capacity, this paper also flaws in many ways.

First, due to the limitation of the questionnaire transceiver's stations, the questionnaire were not uniform and reasonable, and could not exclude the influence of a number of regional or individual logistics enterprises, which could have affected the conclusions; in addition, this study did not take into account the influence of the internal social capital on the innovation of logistics companies. Internal staff's motivation and concept of corporate culture and so on will have impacts on the logistics service innovation. While academics did not consider the domestic logistics enterprises and foreign logistics enterprises' difference, no research results of foreign scholars were compared; finally, this study made no differences in the scope of business segments in accordance with the logistics company and the region. Different logistics companies have different services; different areas and life stages of the logistics company have its own characteristics; these factors are likely to affect the conclusions of empirical research.

Although this study exists various shortcomings, these shortcomings also provide a direction for future research. In future research, first, in order to reduce the impact caused by the sample range of conclusions, scholars should try to conduct nationwide surveys; second, scholars could add internal social capital into future research in order to improve the research framework; third, comparison and absorption between the foreign and domestic research in related areas could do better to future study; fourth, the research index and survey scope need continuous improvement.

\section{Acknowledgements}

I would like to express my gratitude to all those who helped me during the writing of this thesis. Without your consistent and illuminating instruction, this thesis could not have reached its present.

\section{Sponsor}

This work is sponsored by Beijing Wuzi University (item number: 0351601201/013). 


\section{References}

[1] Bao, Y.M. (1997) Bourdieu Interview-Cultural Capital and Social Practice. Shanghai People’s Publishing House, Shanghai, 2-3.

[2] Lcyury, G. (1977) A Dynamic Theory of Racial Income Differences. In: Wallace, P.A. and LeMund, A., Eds., Chapter of Women, Minorities, and Employment Discrimination, Lexington Books, Lexington, MA, 153-186.

[3] Yli-Renko, H., Autio, E. and Sapienza, H.J. (2001) Social Capital, Knowledge Acquisition, and Knowledge Exploitation in Young Technology-Based Firms. Strategy Management Journal, No. 22, 587-613.

[4] Nahapiet, J. and Ghoshal, S. (1997) Social Capital, Intellectual Capital and the Creation of Value in Firms. Academy of Management Best Paper Proceedings, No. 1, 35-39.

[5] Chen, J. and Li, F.Y. (2001) Social Capital: A Sociological of Technological Innovation. Science Research, No. 3, 103107.

[6] Wind, J. and Mahajan, V. (1997) Issues and Opportunities in New Product Development: An Introduction to the Special Issue. Journal of Marketing Research, 34, 1-12. http://dx.doi.org/10.2307/3152060

[7] Xiong, W., Feng, X.B. and Zhang, Q.X. (2010) Continuous Improvement and Incremental Innovation Integration: From the Perspective of Organizational Learning. Scientific Progress and Countermeasures, No. 18, 13-16.

[8] Wu, X.Y. and Li, H. (2013) The Research on the Choice of Inward Oriented Open Innovation Strategy and the Matching of Inward Open Innovation Strategy and Innovation Performance. Science and Technology Management, No. 11, 94-102.

[9] Sun, Y., Chen, T. and Mao, W. (2009) Research on Service Innovation Process Model of Logistics Information Service Enterprise. Modern Management Science, No. 5, 65-67.

[10] Wang, J.B. and Chen, J.X. (2011) Relational Embedding, Learning Ability and Service Innovation PerformanceExploratory Research Based on Multiple Case. Soft Science, No. 1, 19-23.

[11] Heikkinen, M.T., Mainela, T. and Still, J. (2007) Roles for Managing in Mobile Service Development Nets. Industrial Marketing Management, 36, 909-925. http://dx.doi.org/10.1016/j.indmarman.2007.05.014

[12] Damanpour, F. (1991) Organizational Innovation: A Meta-Analysis of Effects of Determinants and Moderators. Academy of management Journal, 34, 555-590. http://dx.doi.org/10.2307/256406

[13] Zhang, H. and Lv, S. (2014) Research on the Relationship between Intellectual Capital, Innovation Types and Product Innovation Performance. Science of Science and Management of S \& T, 35, 162-168.

[14] Lieberman, M.B. and Montgomery, D.B. (1998) First-Mover (Dis)Advantages: Retrospective and Link with the Resource-Based View. Strategic Management Journal, 19, 1111-1125. http://dx.doi.org/10.1002/(SICI)1097-0266(1998120)19:12<1111::AID-SMJ21>3.0.CO;2-W

[15] Szymanski, D.M., Troy, L.C. and Bharadwaj, S.G. (1995) Order of Entry and Business Performance: An Empirical Synthesis and Reexamination. Journal of Marketing, 59, 17-33. http://dx.doi.org/10.2307/1252325

[16] Day, G.S. and Wensley, R. (1988) Assessing Advantage: A Framework for Diagnosing Competitive Superiority. Journal of Marketing, 52, 1-20. http://dx.doi.org/10.2307/1251261

[17] Garcia, R. and Calantone, R. (2002) A Critical Look at Technological Innovation Typology and Innovativeness Terminology: A Literature Review. Journal of Product Innovation Management, 19, 110-132.

[18] Levinthal, D.A. and March, J.G. (1993) The Myopia of Learning. Strategic Management Journal, 14, 95-112. http://dx.doi.org/10.1002/smj.4250141009

[19] Bian, Y. and Qiu, H. (2000) The Social Capital of Enterprises and Its Efficiency. Social Sciences in China, 2, 87-99.

[20] Adler, P.S. and Kwon, S.-W. (2002) Social Capital: Prospects for a New Concept. Academy of Management Review, 27, 17-40.

[21] Zhang, F. (2004) The Research on The Relationship of Social Capital and Technology Innovation Performance of Knowledge Based on Enterprises. Zhejiang University, Zhejiang, 12-17.

[22] Zhang, J. and Duan, Y. (2011) The Impact of Market Orientation on Innovation Types and Product Innovation Performance. Science Research Management, 32, 68-77.

[23] Li, X. (2013) Marketing Innovation of New Transformational Leadership Enterprises into Performance under the Background of the Green Entrepreneurial Orientation: Theoretical Model and Empirical Research in China. Journal of Applied Statistics and Management, 32, 595-607.

[24] Wei, J. and Xu, L. (2014) Knowledge Network Double Embedding, Knowledge Integration and Innovation Capability of Cluster Enterprises. Journal of Management Sciences in China, 17, 34-47.

[25] Zhang, F. (2006) Social Capital of Enterprises and Technology Innovation Performance: Concept Model and Empirical Analysis. R\&D Management, 18, 47-53. 


\section{Submit or recommend next manuscript to SCIRP and we will provide best service for you:}

Accepting pre-submission inquiries through Email, Facebook, LinkedIn, Twitter, etc.

A wide selection of journals (inclusive of 9 subjects, more than 200 journals)

Providing 24-hour high-quality service

User-friendly online submission system

Fair and swift peer-review system

Efficient typesetting and proofreading procedure

Display of the result of downloads and visits, as well as the number of cited articles

Maximum dissemination of your research work

Submit your manuscript at: http://papersubmission.scirp.org/ 